\title{
Media Pembelajaran berbasis Augmented Reality "PRIARMIKA"
}

\author{
I Kadek Mahada Putra, Ni Luh Putu Ning Septyarini Putri Astawa, I Putu \\ Satwika \\ Sekolah Tinggi Manajemen Informatika dan Komputer (STMIK) Primakara \\ E-mail: mahadaputra71320@gmail.com
}

\begin{abstract}
ABSTRAK
Pada penelitian ini membahas tentang rancang bangun aplikasi Android dengan menggunakan teknologi augmented reality yang digunakan dalam mata pelajaran Bahasa Inggris di SMPN 5 Mengwi. Aplikasi yang diberi nama PRIARMIKA (Primakara Augmented Reality Endemic Application) menjelaskan tentang deskripsi hewan endemik yang ditampilkan dalam bentuk 3D. Metode yang digunakan dalam pembuatan aplikasi ini adalah MDLC (Multimedia Development Life Cycle) versi Luther - Sutopo yang terdiri dari enam tahap diantaranya: 1) Concept, 2) Design, 3) Meterial Collecting, 4) Assembly, 5) Testing, 6) Distribution. Aplikasi PRIARMIKA akan divalidasi oleh 3 ahli validator yaitu ahli media, ahli materi dan ahli bahasa. Pengujian aplikasi dilakukan pada kelas VIII SMPN 5 Mengwi sebanyak 28 siswa dan 1 guru Bahasa Inggris. Berdasarkan hasil penelitian, dapat disimpulkan bahwa rancang bangun aplikasi augmented reality PRIARMIKA berbasis Android layak untuk digunakan sebagai media pembelajaran Bahasa Inggris kelas VIII di SMPN 5 Mengwi.
\end{abstract}

Kata Kunci: Media Pembelajaran, Augmented Reality, PRIARMIKA.

\section{PENDAHULUAN}

Dalam tujuan pendidikan, untuk menumbuhkan sikap kritis dan kreatifitas yang tinggi pada siswa diperlukan perhatian yang serius, pergantian kurikulum, dan perkembangan teknologi yang merupakan tantangan karena memerlukan metode dan media yang tepat dalam mendukung konsep pendidikan tersebut (Astawa \& Budiarta, 2019). Dalam pengimplementasian media dan proses pembelajaran, masih digunakan buku teks dan metode penyampaian cara lama, padahal penggunaan media pembelajaran yang tepat dapat mengatasi sifat siswa yang cenderung pasif (Astawa, 2018). Perkembangan teknologi dan perubahan kurikulum masih belum dapat digabungkan dalam media pembelajaran untuk saat ini (Wardani, 2015).

Media adalah bentuk jamak dari kata medium dan berasal dari bahasa latin yaitu medius, yang secara harfiah berarti pengantar atau perantara. Siswa akan terbantu dengan media dalam proses pembelajaran dalam memahami materi pembelajaran yang didapat dan mampu menumbuhkan minat dan motivasi siswa 
dalam proses pembelajaran. Menurut Sadiman dan Raharjo, media adalah berbagai jenis komponan dalam lingkungan siswa yang dapat merangsang siswa untuk belajar (Setiawan \& Nugraha, 2018) sehingga diharapkan dengan media pembelajaran yang mendukung siswa dapat menumbuhkan kreativitas, minat dan semangat dalam mengikuti proses pembelajaran.

Bethany mengemukakan proses belajar adalah penyampaian materi dari guru ke peserta didik. Proses pengubahan materi menjadi simbol komunikasi verbal maupu non-verbal disebut encoding. Penafsiran simbol komunikasi oleh peserta didik disebut dengan decoding. Berhasil tidaknya proses tersebut dinamakan dengan noise/bariere. Media pembelajaran diperlukan guru untuk membantu penyampaian materi dalam sebuah proses pembelajaran. (Kiromi \& Fauziah, 2016)

Proses pembelajaran yang baik memuat aspek interaktif, menyenangkan, menantang, memotivasi, dan memberikan ruang bagi siswa untuk mengembangkan kreatifitas dan kemandirian sesuai dengan minat dan bakatnya. Pemilihan media pembelajaran yang tepat merupakan salah satu faktor dalam meningkatkan minat dan motivasi siswa dalam belajar, namun tidak mengurangi dari segi interaktif serta esensi materi yang disampaikan.

Teknologi informasi dan komunikasi pada masa ini mengalami kemajuan yang pesat, ini dibuktikan dengan banyaknya cara yang dapat digunakan dalam melakukan proses pembelajaran yang dilakukan kepada siswa. Dengan penerapan teknologi informasi dan komunikasi dalam bidang pendidikan, diharapkan dapat memajukan kualitas pendidikan seiring dengan kemajuan teknologi (Saputro \& Saputra, 2014). Salah satu perkembangan media pembelajaran yang saat ini masih baru adalah pengembangan dengan menggunakan teknologi Augmented Reality.

Menurut Trevor dan Maulina, Augmented Reality (AR) adalah istilah yang digunakan untuk menggambarkan bentuk benda nyata yang dihasilkan di komputer. AR adalah teknologi yang dapat memproyeksikan secara real-time benda maya 2D atau 3D ke dalam sebuah lingkungan nyata. Menurut Azuma, teknologi AR memiliki tiga karakteristik, diantaranya (Saputro \& Saputra, 2014):

a. Kombinasi pada dunia nyata dan virtual

b. Interaksi yang berjalan secara real-time

c. Bentuk objek yang berupa model 3 dimensi (3D)

Augmented Reality (AR) berguna dalam membantu memvisualisasikan suatu konsep abstrak untuk pengenalan dan pemahaman suatu obyek. Aplikasi AR dirancang untuk memberikan informasi yang lebih detail bagi pengguna dari suatu obyek nyata. Dengan semakin lengkapnya dan perkembangan teknologi saat ini, penerapan AR menjadi salah satu alternatif dari media pembelajaran yang tersedia.

Dalam penelitian ini, peneliti akan merancang sebuah media pembelajaran berbasis AR yang difokuskan dalam tujuannya untuk mendukung proses belajar Bahasa Inggris siswa dengan tema "Hewan Endemik Indonesia". Tema ini diambil berdasarkan dari hasil observasi yang dilakukan terhadap tujuan pembelajaran 
serta silabus yang digunakan oleh siswa kelas VIII SMPN 5 Mengwi dalam proses belajar mengajar di dalam kelas. Adapun aplikasi yang dibuat akan dinamai dengan nama "PRIARMIKA" (Primakara Augmented Reality Endemic Application).

PRIARMIKA adalah nama aplikasi yang peneliti gunakan untuk membantu media pembelajaran dengan tujuan untuk meningkatkan minat siswa - siswi dalam proses belajar mengajar Bahasa Inggris, terutama dalam pembahasan sub bab deskripsi. PRIARMIKA akan menampilkan objek 3D hewan endemik beserta dengan deskripsi dalam bentuk Bahasa Inggris mengenai hewan tersebut. PRIARMIKA memiliki fitur audio sehingga ketika digunakan, hewan endemik yang di-scan akan dijelaskan dalam bentuk audio berbahasa Inggris. Dengan bentuk hewan yang dapat diatur besar kecilnya dan dapat diputar diharapkan dapat menarik minat siswa - siswi SMPN 5 Mengwi kelas VIII dalam mempelajari materi deskripsi hewan endemik pada mata pelajaran Bahasa Inggris.

Beberapa penelitian yang telah dilakukan dengan menggunakan teknologi AR untuk media pembelajaran diantaranya dilakukan oleh Franciska di tahun 2018 dan Wardani pada tahun 2015. Penelitian yang dilakukan oleh Franciska di MI Ma'Árif Patihan Kidul yang menggunakan teknologi AR untuk media pembelajaran menghasilkan bahwa aplikasi media pembelajaran AR dapat diterima dan disukai oleh pengguna siswa - siswi yang dibuktikan dengan presentase ketuntasan nilai yang mengalami peningkatan sebesar 30\%, yang dimulai dari pra siklus, siklus I dan siklus II. Pembelajaran AR dapat membuat pengguna (siswa - siswi) menjadi senang dan tertarik saat menggunakannya sehingga siswa dan siswi menjadi semakin bersemangat dalam mengikuti pembelajaran (Acesta \& Nurmaylany, 2018).

Penelitian Wardani mengenai pengenalan aksara jawa pada anak menghasilkan bahwa penggunaan AR dalam membuat aksara jawa menjadi bentuk 3D sehingga dapat digunakan secara efektif dalam pembelajaran. Akan tetapi dalam penggunaan marker masih berwarna hitam putih sehingga terkesan tidak menarik daripada marker yang dikemas dalam bentuk katalog (Franciska, Setyawan, \& Zulkarnain, 2018).

Selanjutnya adalah penelitian yang dilakukan oleh Nugraha pada tahun 2016 berjudul rancang bangun aplikasi Android AR museum Bali: gedung karangasem dan gedung tabanan aplikasi AR Museum Bali, yang menghasilkan aplikasi AR yang memberikan pengalaman baru bagi masyarakat dalam mencari informasi mengenai benda bersejarah di Museum Bali (Nugraha, Putra, \& Sukasa, 2016).

Penelitian dari Sung, Ma, Choi dan Hong pada tahun 2019 yang berjudul real-time augmented reality physics simulator for education. Penelitian ini bertujuan untuk menyediakan konten pendidikan yang lebih fleksibel dengan memberikan teknologi simulasi secara real-time untuk mata pelajaran fisika. Alur dan tahapan tahapan dalam perancangan aplikasi ini dibagi menjadi initialization step, environment step, dan simulation step sequence (Sung, Ma, Choi, \& Hong, 2019). 


\section{METODE PENELITIAN}

Pada penelitian ini, metode yang digunakan yaitu MDLC (Multimedia Development Life (ycle) versi Luther-Sutopo. Metode ini dapat digunakan dalam pembuatan animasi, film, maupun aplikasi multimedia. Sutopo mengungkapkan terdapat enam tahapan dalam pengembangan multimedia diantaranya tahapan concept, design, material collecting, assembly, testing dan distribution (Mustika, 2018).

Gambar 1. Metode MDLC Versi Luther - Sutopo

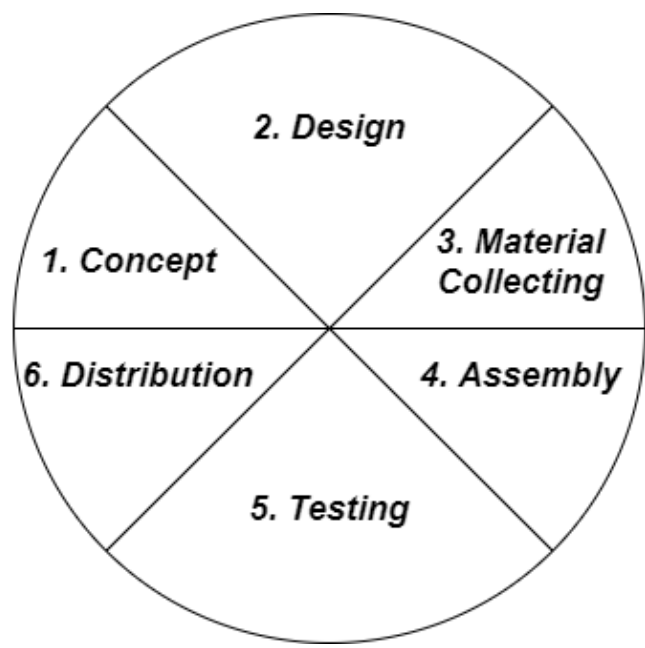

Sumber: (Mustika, 2018)

Tahap concept ditentukan berdasarkan data - data yang dikumpulkan melalui hasil wawancara yang telah dilakukan sebagai kebutuhan dalam membuat aplikasi AR. Selain wawancara, peneliti juga menggunakan catatan lapangan (field note) untuk mendukung dalam pembuatan konsep aplikasi AR. Pada tahap design peneliti melakukan pembuatan program perangkat lunak, tampilan antar muka, dan melakukan prosedur pengkodean. Dalam tahap Material Collecting, peneliti mengumpulkan bahan yang akan digunakan sesuai kebutuhan untuk membuat aplikasi AR. Bahan yang dikumpulkan dapat berupa audio, gambar, dan juga teks. Adapun bahan yang akan dikumpulkan adalah foto hewan endemik yang akan digunakan untuk membuat asset 3D, deskripsi hewan endemik, dan suara yang akan digunakan untuk menjelaskan deskripsi hewan endemik. Tahap assembly peneliti mulai untuk menggabungkan dan membuat aplikasi AR. Proses pembuatan tersebut meliputi pembuatan aset 3D hewan endemik, audio dan teks untuk deskripsi. Aplikasi PRIARMIKA akan melewati tahap testing untuk mengetahui apakah aplikasi yang telah dibuat berjalan dengan baik. Jika terjadi kesalahan, maka akan dilakukan revisi dan perbaikan agar aplikasi dapat berjalan lebih baik. Pengujian aplikasi AR menggunakan black box testing. Pengujian black box dilakukan untuk mengetahui kesalahan yang terjadi pada aplikasi, seperti fungsi yang berjalan tidak benar atau hilang, kesalahan desain muka (interface), 
kesalahan kinerja seperti kesalahan inisiasi atau terminasi. Selain penggunaan black box, peneliti menggunakan kuesioner untuk mendukung hasil testing dari aplikasi AR. Dalam kuesioner akan dinilai apakah aplikasi yang telah dibuat dapat menghasilkan apliasi AR yang berkualitas menurut pengguna. Dalam tahap distribution, aplikasi beberapa kali diuji coba dan lolos pada tahap pengujian, pembuatan master file akan dilakukan dan akan disebarluaskan kepada pengguna, yaitu siswa kelas VIII G sebanyak 28 siswa dan 1 guru mata pelajaran Bahasa Inggris di SMPN 5 Mengwi.

\section{Teknik Pengumpulan dan Jenis Data}

Peneliti mengumpulkan data dengan teknik wawancara, observasi, studi literatur, dan kuesioner. Wawancara dilakukan kepada guru Bahasa Inggris SMPN 5 Mengwi dengan tujuan untuk mengetahui kebutuhan dalam pengembangan media pembelajaran Bahasa Inggris. Metode wawancara yang peneliti gunakan adalah wawancara tidak terstruktur agar peneliti mendapatkan informasi secara akurat mengenai apa yang narasumber selaku guru Bahasa Inggris benar - benar butuhkan dalam mengembangkan media pembelajaran, berdasarkan situasi yang terjadi di SMPN 5 Mengwi. Dalam observasi, peneliti mengamati secara langsung media pembelajaran yang digunakan dalam kegiatan belajar mengajar pada mata pelajaran Bahasa Inggris siswa kelas VIII G dengan guru Bahasa Inggris di SMPN 5 Mengwi. Studi literatur dilakukan saat sebelum penelitian, dimana peneliti mencari, mengumpulkan, dan mempelajari jurnal yang berkaitan dengan penelitian ini. peneliti menggunakan dua jenis kuesioner yang berbeda yaitu kuesioner tertutup yang nantinya akan diisi oleh siswa dan guru SMPN 5 Mengwi serta kuesioner terbuka dan tertutup untuk tiga ahli validasi. Tiga ahli validasi tersebut diantaranya ahli media atau desain yang berfungsi untuk memvalidasi desain tampilan dari aplikasi PRIARMIKA, ahli materi dengan tujuan agar deskripsi hewan endemik aplikasi PRIARMIKA sesuai dengan materi deskripsi Bahasa Inggris kelas VIII dan ahli bahasa agar aplikasi PRIARMIKA memiliki kosakata, grammar, penyampaian deskripsi lisan hewan endemik yang baik dan benar dalam Bahasa Inggris.

Pada jenis data, data kualitatif yang digunakan dalam penelitian ini adalah data yang didapat dari hasil wawancara dengan guru pembimbing bahasa Inggris, serta saran dan masukan dari siswa - siswi kelas VIII SMPN 5 Mengwi. Wawancara tersebut membahas tentang tampilan dan fitur yang ada pada aplikasi AR. Untuk saran serta masukan yang dimaksud adalah hasil pengimplementasian aplikasi AR terhadap siswa dan siswi kelas VIII SMPN 5 Mengwi. Data kuantitatif diperoleh dari hasil kuesioner yang diberikan kepada guru, dan siswa SMPN 5 Mengwi.

Penelitian yang dilakukan oleh peneliti berlokasi di Jalan Ktr. Lurah, Sading, Kec. Mengwi, Kabupaten Badung, Bali 80115. Penelitian dilakukan pada bulan November 2019 sampai bulan Mei 2020. 


\section{HASIL DAN PEMBAHASAN}

Dalam proses pembuatan aplikasi PRIARIMIKA, peneliti menggunakan metode Luther-Sutopo. Metode ini memiliki 6 (enam) tahapan diantaranya concept, design, material collecting, assembly, testing dan distribution.

\section{Tahap Concept}

Pada tahap ini, peneliti melakukan wawancara dan observasi kepada guru Bahasa Inggris di SMPN 5 Mengwi dan dihasilkan bahwa pembelajaran Bahasa Inggris di SMPN 5 Mengwi masih menggunakan metode konvensional sehingga membuat siswa - siswi merasa jenuh dalam proses pembelajaran. Berdasarkan hal tersebut, maka dikonsepkan sebuah aplikasi AR yang akan digunakan sebagai media pembelajaran Bahasa Inggris untuk siswa - siswi di SMPN 5 Mengwi. Aplikasi AR ini menjelaskan tentang deskripsi hewan endemik yang ada di Indonesia. Deskripsi hewan endemik dipilih sebagai konsep dari aplikasi AR karena rekomendasi dari guru Bahasa Inggris selaku narasumber dalam wawancara yang peneliti lakukan.

\section{Tahap Design}

Pada tahap ini peneliti mulai mendesain marker AR sebagai media scan dari aplikasi PRIARMIKA. Peneliti juga mengumpulkan beberapa gambar hewan Endemik Indonesia yang akan digunakan dalam aplikasi PRIARMIKA. Selain mendesain aplikasi, peneliti sekaligus melakukan tahap material collecting mengingat pengerjaan aplikasi ini memerlukan waktu yang cukup panjang.

Dalam tahap design, pengerjaan dimulai dari mendesain marker dan membuat texture asset. Model 3D (dimensi) yang digunakan merupakan model 3D yang peneliti download di web www.cadnav.com dan www.free3d.com. Saat marker discan, maka akan muncul tampilan 3 (tiga) dimensi gambar hewan, yang dapat dilihat pada gambar di bawah:

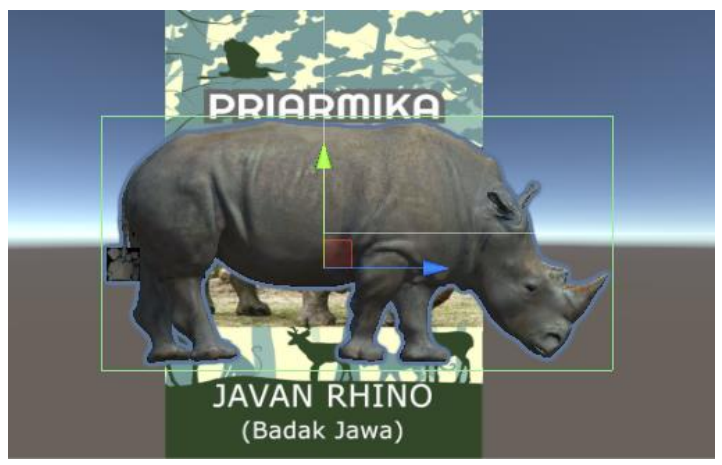

Gambar 2. Tampilan Pembuatan PRIARMIKA Badak Jawa 


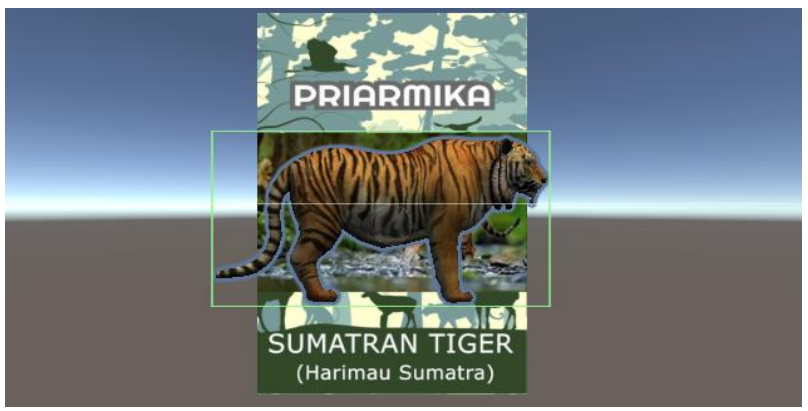

Gambar 3. Proses Pembuatan PRIARMIKA Harimau Sumatra

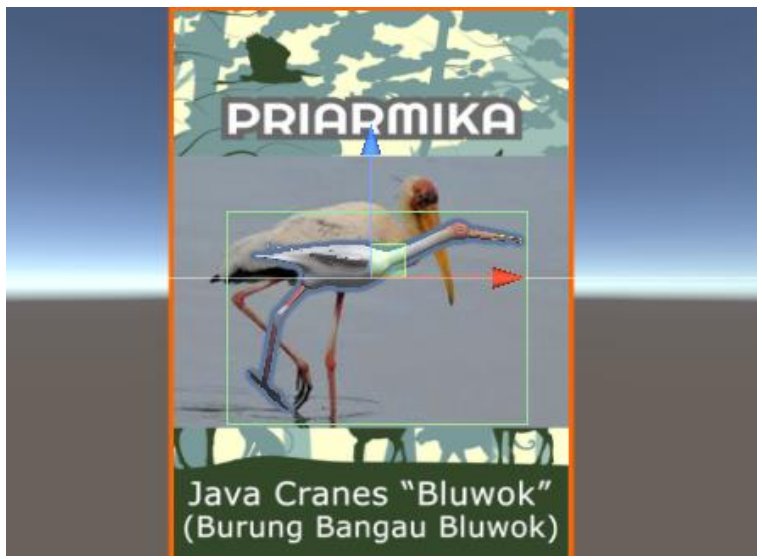

Gambar 4. Proses Pembuatan PRIARMIKA Bluwok

\section{Tahap Material Collecting}

Pada tahap ini asset 3D akan diberikan script agar dapat digerakkan, diperbesar maupun diperkecil, serta dapat diputar. Material lainnya berupa deskripsi hewan endemik, suara dan marker AR akan dimasukan ke dalam aplikasi. Selain itu, peneliti juga melakukan tahap assembly bersamaan dengan mengumpulkan materi untuk mempercepat waktu pembuatan aplikasi. Dalam tahap ini juga dilakukan perbandingan antara asset 3D dengan marker AR apakah asset 3d sudah mendekati kemiripan dengan gambar pada marker AR. Pada asset 3D juga dilakukan pengecekan apakah script sudah dimiliki oleh setiap asset. Selain itu pengecekan deskripsi tulisan pada AR, dan suara juga dilakukan untuk meminimalisir kesalahan yang didapat.

Dalam pembuatan AR PRIARMIKA, terdapat 3 (tiga) aspek yang akan peneliti uji dengan kuesioner agar aplikasi ini menjadi valid diantaranya aspek materi, media dan bahasa. Pada aspek materi dan media, peneliti menggunakan kuesioner yang sudah divalidasi pada penelitian sebelumnya oleh Nurwanti pada tahun 2017. Untuk aspek bahasa peneliti menggunakan kuesioner dari Kusuma pada tahun 2018 yang juga sudah dilakukan validasi pada penelitian sebelumnya.

\section{Tahap Assembly}

Penyusunan event - event yang ada mulai dilakukan pada tahap ini dan juga pengecekan kembali pada gambar untuk memastikan asset 3D sudah sesuai pada 
marker atau kartunya. Di dalam tahap ini peneliti membuat use case diagram untuk pengguna agar dapat menggunakan aplikasi PRIARMIKA yang akan dijelaskan pada gambar di bawah :

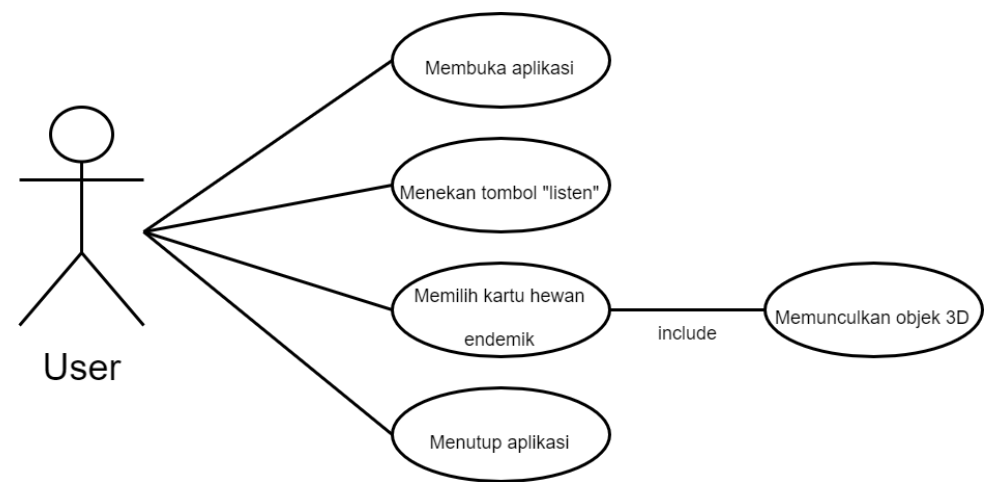

Gambar 4.1.5 Use Case Diagram Pengguna Aplikasi PRIARMIKA Activity Diagram aplikasi secara detail dapat dilihat pada gambar berikut :

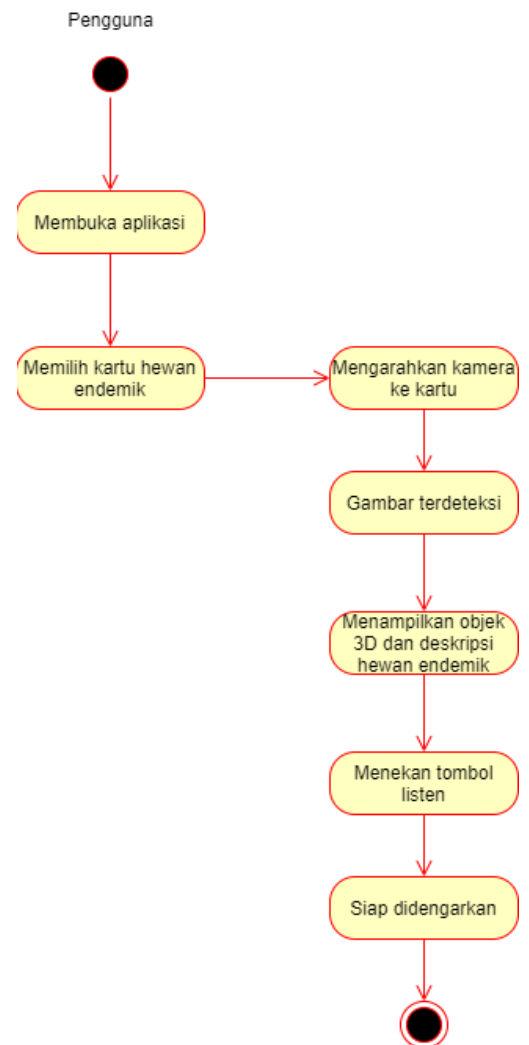

Gambar 4.1.6 Activity Diagram pada pengguna Aplikasi PRIARMIKA

\section{Tahap Testing}

Peneliti menggunakan metode pengujian Black Box dalam tahap ini, dimana peneliti hanya ingin melihat apakah aplikasi telah bekerja sesuai dengan keinginan peneliti. Poin - poin pengetesan yang telah dilakukan peneliti rangkum dan disajikan pada tabel yang ada di bawah: 


\begin{tabular}{|c|c|c|c|}
\hline No & Skenario Pengujian & Hasil Yang Diharapkan & Hasil \\
\hline 1 & $\begin{array}{l}\text { User mengarahkan kamera } \\
\text { kearah kartu AR Harimau } \\
\text { Sumatra }\end{array}$ & $\begin{array}{l}\text { Muncul objek 3D Harimau } \\
\text { Sumatra dan deskripsinya secara } \\
\text { tertulis dalam Bahasa Inggris }\end{array}$ & Valid \\
\hline 2 & $\begin{array}{l}\text { User menekan tombol listen } \\
\text { pada deskripsi Harimau } \\
\text { Sumatra }\end{array}$ & $\begin{array}{l}\text { Aplikasi mengeluarkan suara } \\
\text { Bahasa Inggris dan menjelaskan } \\
\text { deskripsi Harimau Sumatra sesuai } \\
\text { dengan text }\end{array}$ & Valid \\
\hline 3 & $\begin{array}{l}\text { User mengarahkan kamera } \\
\text { kearah kartu AR Gajah } \\
\text { Sumatra }\end{array}$ & $\begin{array}{l}\text { Muncul objek 3D Gajah Sumatra } \\
\text { dan deskripsinya secara tertulis } \\
\text { dalam Bahasa Inggris }\end{array}$ & Valid \\
\hline 4 & $\begin{array}{l}\text { User menekan tombol listen } \\
\text { pada deskripsi Gajah Sumatra }\end{array}$ & $\begin{array}{l}\text { Aplikasi mengeluarkan suara } \\
\text { Bahasa Inggris dan menjelaskan } \\
\text { deskripsi Gajah Sumatra sesuai } \\
\text { dengan text }\end{array}$ & Valid \\
\hline 5 & $\begin{array}{l}\text { User mengarahkan kamera } \\
\text { kearah kartu AR Badak Jawa }\end{array}$ & $\begin{array}{l}\text { Muncul objek 3D Badak Jawa dan } \\
\text { deskripsinya secara tertulis dalam } \\
\text { Bahasa Inggris }\end{array}$ & Valid \\
\hline 6 & $\begin{array}{l}\text { User menekan tombol listen } \\
\text { pada deskripsi Badak Jawa }\end{array}$ & $\begin{array}{l}\text { Aplikasi mengeluarkan suara } \\
\text { Bahasa Inggris dan menjelaskan } \\
\text { deskripsi Badak Jawa sesuai } \\
\text { dengan text }\end{array}$ & Valid \\
\hline 7 & $\begin{array}{l}\text { User mengarahkan kamera } \\
\text { kearah kartu AR Banteng } \\
\text { Jawa }\end{array}$ & $\begin{array}{l}\text { Muncul objek 3D Banteng Jawa } \\
\text { dan deskripsi secara tertulis dalam } \\
\text { Bahasa Inggris }\end{array}$ & Valid \\
\hline 8 & $\begin{array}{l}\text { User menekan tombol listen } \\
\text { pada deskripsi Banteng Jawa }\end{array}$ & $\begin{array}{l}\text { Aplikasi mengeluarkan suara } \\
\text { Bahasa Inggris dan menjelaskan } \\
\text { deskripsi Banteng Jawa sesuai } \\
\text { dengan text }\end{array}$ & Valid \\
\hline 9 & $\begin{array}{l}\text { User mengarahkan kamera } \\
\text { kearah kartu AR Bluwok }\end{array}$ & $\begin{array}{l}\text { Muncul objek 3D Bluwok dan } \\
\text { deskripsinya secara tertulis dalam } \\
\text { Bahasa Inggris }\end{array}$ & Valid \\
\hline 10 & $\begin{array}{l}\text { User menekan tombol listen } \\
\text { pada deskripsi Bluwok }\end{array}$ & $\begin{array}{l}\text { Aplikasi mengeluarkan suara } \\
\text { Bahasa Inggris dan menjelaskan } \\
\text { deskripsi Bluwok sesuai dengan } \\
\text { text }\end{array}$ & Valid \\
\hline 11 & $\begin{array}{l}\text { User mengarahkan kamera } \\
\text { kearah kartu AR Komodo }\end{array}$ & $\begin{array}{l}\text { Muncul objek 3D Komodo dan } \\
\text { deskripsinya secara tertulis dalam } \\
\text { Bahasa Inggris }\end{array}$ & Valid \\
\hline 12 & User menekan tombol listen & Aplikasi mengeluarkan suara & Valid \\
\hline
\end{tabular}




\begin{tabular}{|c|l|l|l|}
\hline & pada deskripsi Komodo & $\begin{array}{l}\text { Bahasa Inggris dan menjelaskan } \\
\text { deskripsi Komodo sesuai dengan } \\
\text { text }\end{array}$ & \\
\hline $\mathbf{1 3}$ & $\begin{array}{l}\text { User mengarahkan kamera } \\
\text { kearah kartu AR Surili }\end{array}$ & $\begin{array}{l}\text { Muncul objek 3D Surili dan } \\
\text { deskripsinya secara tertulis dalam } \\
\text { Bahasa Inggris }\end{array}$ & Valid \\
\hline $\mathbf{1 4}$ & $\begin{array}{l}\text { User menekan tombol listen } \\
\text { pada deskripsi Surili }\end{array}$ & $\begin{array}{l}\text { Aplikasi mengeluarkan suara } \\
\text { Bahasa Inggris dan menjelaskan } \\
\text { deskripsi Surili sesuai dengan text }\end{array}$ & Valid \\
\hline
\end{tabular}

Tabel 4.1 Tabel Pengujian Black Box Texting Pada Aplikasi PRIARMIKA

\section{Tahap Distribution}

Pendistribusian aplikasi dilakukan di Google Play Store milik Android. Hampir semua siswa - siswi, orang tua siswa serta guru di SMP Negeri 5 Mengwi menggunakan perangkat handphone dengan sistem operasi Android. Pada penelitian ini, pengembangan aplikasi masih sebatas pada penggunaan Android dan diharapkan kedepannya akan ada yang melanjutkan penelitian ini untuk mengembangkannya pada sistem operasi yang berbeda selain Android.

Hasil dari kuesioner yang peneliti dapatkan, yaitu melibatkan 29 responden yang terdiri dari 28 siswa dari kelas VIII G dan 1 guru Bahasa Inggris yang mengisi form kuesioner dan mendapatkan respon positif. Pada aplikasi memberikan manfaat dalam penjelasan hewan endemik peneliti mendapat tanggapan yaitu cukup sebesar 3,4\% (1 responden), setuju 44,8\% (13 responden), dan sangat setuju sebesar 51,7\% (15 responden). Pada pertanyaan aplikasi PRIARMIKA efektif digunakan pada materi deskriptif dalam Bahasa Inggris peneliti mendapatkan respon cukup yaitu 10,3\% (3 responden), setuju 51,7\% (15 responden) dan sangat setuju sebesar 37,9\% (11 responden). Pertanyaan mengenai aplikasi PRIARMIKA mudah untuk dipahami oleh siswa - siswa memperoleh tanggapan cukup sebesar $17,2 \%$ (5 responden), setuju 65,5\% (19 responden) dan sangat setuju sebesar 17,2\% (5 responden). Selanjutnya mengenai tampilan PRIARMIKA terlihat menarik memperoleh angka pada respon cukup sebesar 13,8\% (4 responden), setuju sebesar 48,3\% (14 responden) dan sangat setuju sebesar 37,9\% (11 responden). Aplikasi PRIARMIKA sesuai dengan kebutuhan siswa memperoleh tanggapan cukup sebesar 34,5\% (10 responden), setuju 51,7\% (15 responden) dan sangat setuju 13,8\% (4 responden) dan terakhir PRIARMIKA mudah untuk digunakan mendapat respon cukup sebesar 6,9\% (2 responden), setuju 55,2\% (16 responden), dan sangat setuju sebesar 37,9\% (11 responden). Berdasarkan hasil kuesioner diatas, peneliti menyimpulkan bahwa aplikasi PRIARMIKA telah sesuai dengan tujuan peneliti yaitu mengembangkan media pembelajaran berbasis teknologi yang menarik dan sesuai dengan kebutuhan siswa serta guru. PRIARMIKA dapat membantu siswa sebagai media pembelajaran bahasa Inggris pada materi deskripsi sehingga kebutuhan dan tujuan peneliti dalam penelitian ini telah terpenuhi. 
Aplikasi PRIARMIKA telah melalui proses validasi pada bagian media, materi, dan bahasa. Hasil yang didapatkan pada validasi media, PRIARMIKA mendapatkan respon yang baik dari segi tampilan yang interaktif, sederhana, dan mudah dipahami. Pada validasi materi, deskripsi hewan endemik pada PRIARMIKA sudah sesuai dengan materi deskripsi siswa SMP kelas VIII. Dalam validasi bahasa terdapat perbaikan sebanyak satu kali yang akan peneliti sajikan pada tabel di bawah:

\section{Keterangan:}

$\begin{array}{ll}\text { Sangat Tidak Setuju } & : 1 \\ \text { Tidak Setuju } & : 2 \\ \text { Cukup } & : 3 \\ \text { Setuju } & : 4 \\ \text { Sangat Setuju } & : 5\end{array}$

\begin{tabular}{|c|l|c|c|}
\hline No & \multicolumn{1}{|c|}{ Kriteria Penliaian } & Hasil Pertama & Hasil Kedua \\
\hline 1 & Kelengkapan deskripsi & 3 & 4 \\
\hline 2 & Relevan dengan hewan endemik & 4 & 4 \\
\hline 3 & Kesesuaian gambar dengan model 3D & 4 & 4 \\
\hline 4 & Ketepatan penyampaian deskripsi & 2 & 4 \\
\hline 5 & Kebenaran penyampaian kosa kata & 2 & 4 \\
\hline 6 & Menumbuhkan rasa ingin tahu & 3 & 4 \\
\hline 7 & Mempermudah belajar bahasa Inggris & 4 & 4 \\
\hline 8 & Memotivasi siswa dalam belajar & 3 & 4 \\
\hline 9 & Berpusat pada siswa & 4 & 4 \\
\hline
\end{tabular}

Hasil kuesioner pertama, perbaikan dalam hal penyampaian deskripsi dan kosa kata mendapat nilai yang rendah sehingga dilakukan perbaikan. Pada penilaian kedua telah dilakukan perbaikan dan penyesuaian pada kriteria lainnya sehingga aplikasi PRIARMIKA mendapatkan nilai setuju dan PRIARMIKA telah memenuhi validasi dari segi bahasa.

\section{KESIMPULAN DAN SARAN}

Pada pembahasan yang telah peneliti uraikan di bab-bab sebelumnya tentang Rancangan Media Pembelajaran Bahasa Inggris Berbasis Android Menggunkan Teknologi Augmented Reality (AR) Untuk Siswa Kelas VIII SMPN 5 Mengwi dengan menggunakan metode Luther - Sutopo, dapat ditarik kesimpulan bahwa yaitu dalam proses pembuatan aplikasi PRIARMIKA pada bagian asset dan texturing memakan lebih banyak waktu daripada bagian lainnya, dimana dalam pembuatan asset dan proses texturing harus semirip mungkin dengan hewan endemik yang terdapat pada marker AR.

Peneliti telah melakukan perbaikan pada aplikasi berdasarkan hasil data 
yang telah diperoleh dari hasil kuesioner validasi ahli bahasa, materi, dan desain. Sehingga, pada pengambilan kuesioner kedua didapatkan data yang lebih baik dari kuesioner sebelumnya dikarenakan adanya peningkatan kualitas dari aplikasi baik secara materi, bahasa, maupun media. Selain itu, berdasarkan hasil Black Box Testing didapati bahwa seluruh skenario yang dirancang sudah valid atau sesuai dengan hasil yang diharapkan. Untuk hasil uji coba selanjutnya didapat dari pengguna yang dimana data menunjukan hasil yang positif sehingga dapat disimpulkan bahwa media ini layak untuk digunakan sebagai aplikasi pembelajaran berbasis AR untuk siswa kelas VIII di SMPN 5 Mengwi

Adapun saran dari peneliti yang ingin sampaikan agar studi selanjutnya dapat dikembangkan pada sistem operasi selain Android, yaitu sistem operasi iOS serta pada aplikasi dapat ditambahkan lebih banyak hewan endemik Indonesia, lengkap dengan deskripsi secara tertulis dan lisan.

\section{DAFTAR PUSTAKA}

Acesta, A., \& Nurmaylany, M. (2018). Pengaruh Penggunaan Augmented Reality Terhadap Hasil Belajar Siswa. Jurnal Pendidikan Guru Sekolah Dasar, IV(2), 348.

Astawa, N. L. (2018). The Impact of Project-Based Instruction on Students' Engagement and Speaking Skills. Widya Accarya, 9.

Astawa, N. L., \& Budiarta, L. G. (2019). Model Pembelajaran Berbasis Proyek: Pengaruhnya Terhadap Kemampuan Berbicara Dan Proses Belajar. III(1), 71.

Franciska, M. B., Setyawan, M. B., \& Zulkarnain, I. A. (2018). Rancang Bangun Media Pembelajaran Bahasa Inggris Berbasis Android Menggunakan Teknologi Augmented Reality untuk Sekolah Dasar (Studi Kasus MI Ma'Arif Patihan Kidul). Penerbitan Artikel Ilmiah Mahasiswa Universitas Muhammadiyah Ponorogo, 50.

Kiromi, I. H., \& Fauziah, P. Y. (2016). Pengembangan Media Pembelajaran Big Book Untuk Pembentukan Karakter Anak Usia Dini. Jurnal Pendidikan dan Pemberdayaan Masyarakat, 3(1), 49.

Mustaqim, I. S., \& Kurniawan, N. (2017). Pengembangan Media Pembelajaran Berbasis Augmented Reality. Jurnal Edukasi Elektro, I(1), 37.

Mustika. (2018). Rancang Bangun Aplikasi Sumsel Museum Berbasis Mobile Menggunakan Metode Pengembangan Multimedia Development Life Cycle (MDLC). Jurnal Mikrotik, VIII(1), 5.

Nugraha, I. G., Putra, I. K., \& Sukasa, I. M. (2016). Rancang Bangun Aplikasi Android AR Museum Bali : Gedung Karangasem dan Gedung Tabanan. Lontar Komputer, VII(2), 95. 
Saputro, R. E., \& Saputra, D. I. (2014). Pengembangan Media Pembelajaran Mengenal Organ Pencernaan Manusia Menggunakan Teknologi Augmented Reality. 6(2), 156.

Setiawan, A. B., \& Nugraha, A. C. (2018). Pengembangan Media Pembelajaran Berbasis Augmented Reality Pengenalan Komponen Sistem Kendali Elektrmagnetik. Prodi Pendidikan Teknik Elektro, 8(5), 355.

Sung, N.-J., Ma, J., Choi, Y.-J., \& Hong, M. (2019). Real-Time Augmented Reality Physics Simulator for Education. 4.

Wardani, S. (2015). Pemanfaatan Teknologi Augmented Reality (AR) Untuk Pengenalan Aksara Jawa Pada Anak. Jurnal Dinamika Informatika, V(1), 2. 